\title{
PENGARUH PENGGUNAAN MEDIA PEMBELAJARAN KREATIF TERHADAP HASIL BELAJAR IPS SISWA SEKOLAH DASAR NEGERI DI SURABAYA SELATAN
}

\author{
A. Qomaru Zaman \\ Dwi Retnani S \\ Dosen Prodi PPKn - FKIP - UNIPA Surabaya \\ qomarpkn@gmail.com
}

\begin{abstract}
Abstrak
Media pembelajaran kreatif merupakan media yang dirancang dan dibuat sendiri oleh guru, dalam rangka mempermudah dan memperlancar proses transformasi ilmu pengetahuan, termasuk Ilmu Pengetahuan Sosial (IPS) kepada siswa. Dengan media pembelajaran kreatif maka konsep-konsep IPS SD yang abstrak dapat diubah menjadi lebih konkrit sehingga mudah diterima dan dicerna oleh peserta didik. Penelitian ini bertujuan untuk "mengkaji pengaruh penggunaan media pembelajaran kreatif terhadap hasil belajar IPS siswa Sekolah Dasar Negeri di Surabaya Selatan.

Jenis penelitian ini adalah penelitian kuantitatif True Experimental Design dengan jenis postestonly control design. Populasinya seluruh siswa kelas IV dan V Sekolah Dasar Negeri di Surabaya. Sedangkan sampelnya adalah siswa kelas IV dan V di lima SDN di 4 kecamatan dalam lingkup Surabaya Selatan. Pengumpulan data dilakukan dengan teknik tes dan observasi, sedangkan analisisnya dengan uji $t$. Simpulan yang diperoleh ialah ada pengaruh yang signifikan penggunaan Media Pembelajaran Kreatif terhadap hasil belajar IPS siswa Sekolah Dasar Negeri di Surabaya Selatan.
\end{abstract}

Kata Kunci: Media pembelajaran kreatif, hasil belajar, IPS.

\section{Pendahuluan}

Undang-Undang Republik Indonesia Nomor 20 Tahun 2003 Tentang Sistem Pendidikan Nasional (UU Sisdiknas) merumuskan fungsi dan tujuan pendidikan nasional yang harus digunakan dalam upaya mengembangkan pendidikan di Indonesia. Pada pasal 3, UU Sisdiknas menyebutkan, "Pendidikan Nasional berfungsi mengembangkan dan membentuk watak serta peradaban bangsa yang bermartabat dalam rangka mencerdaskan kehidupan bangsa, bertujuan untuk berkembangnya potensi peserta didik agar menjadi manusia yang beriman dan bertakwa kepada Tuhan Yang Maha Esa, berakhlak mulia, sehat, berilmu, cakap, kreatif, mandiri, dan menjadi warga negara yang demokratis serta bertanggung jawab". Tujuan pendidikan nasional itu merupakan rumusan mengenai kualitas manusia Indonesia yang harus dikembangkan oleh setiap satuan pendidikan.
Kualitas pendidikan tidak dapat dipisahkan dari proses yang paling dasar, yaitu proses pembelajaran di kelas. Kualitas pembelajaran di kelas tidak dapat lepas dari beberapa aspek, seperti profesionalisme guru, perkembangan dan pertumbuhan peserta didik, tujuan pendidikan dan pembelajaran, perencanaan pembelajaran, strategi pembelajaran, dan media pembelajaran. Dengan kata lain perangkat pembelajaran yang terdiri dari Silabus, Rencana Pelaksanaan Pembelajaran (RPP), Materi Ajar, Lembar Kegiatan Siswa (LKS), dan Lembar Penilaian (Evaluasi) serta Media Pembelajaran, merupakan komponen yang sangat menentukan kualitas pembelajaran.

Penelitian ini lebih mengkhususkan lagi pada komponen media pembelajaran. Menurut Trianto (2011:156), media pembelajaran adalah sebuah alat yang berfungsi untuk menyampaikan pesan pembelajaran. Dalam proses pembelajaran 
diperlukan sebuah alat yang mempunyai fungsi untuk menyampaikan materi yang akan diajarkan. Dengan demikian media pembelajaran merupakan alat bantu dalam proses pembelajaran untuk mempermudah proses penerimaan siswa terhadap materi pembelajaran yang disampaikan oleh guru dalam rangka mencapai tujuan pembelajaran.

Namun dalam realitas pembelajaran di sekolah dasar, guru masih sangat terbatas dalam menggunakan media pembelajaran. Alasan guru umumnya karena rumit membuatnya dan mahal harganya, sehingga mereka tidak mampu membuat dan membeli media pembelajaran. Media pembelajaran sebenarnya tidak harus media yang canggih dan mahal. Media pembelajaran dapat diperoleh dari lingkungan sekitar. Oleh karena itu diperlukan kreativitas guru dalam menciptakan media dari alam sekitar.

Ilmu Pengetahuan Sosial (IPS) merupakan ilmu pengetahuan yang di dalamnya mempelajari dan mengkaji mengenai masalah-masalah sosial yang terjadi dalam kehidupan sehari-hari, yang mendidik dan melatih peserta didik agar mempunyai keterampilan-keterampilan yang berguna untuk menjalani kehidupan sehari-harinya.

Agar tujuan pembelajaran dalam materi

Ilmu Pengetahuan Sosial dapat terserap dengan baik, maka guru harus melakukan inovasi dalam pembelajaran. Salah satu inovasi yang dapat dilakukan adalah menciptakan media pembelajaran kreatif. Media pembelajaran kreatif merupakan media yang dirancang dan dibuat sendiri oleh guru, dalam rangka mempermudah dan memperlancar proses transformasi Ilmu Pengetahuan Sosial kepada siswa. Dengan media pembelajaran kreatif maka konsepkonsep IPS SD yang abstrak dapat diubah menjadi lebih konkrit sehingga mudah diterima dan dicerna oleh peserta didik.

Dari pemaparan pemikiran tersebut di atas, maka pembelajaran IPS di SD akan lebih mudah diterima, jika menggunakan media pembelajaran kreatif yang menarik. Media pembelajaran idealnya yang mampu membuat siswa senang dan tertarik, serta memberikan ruang kepada siswa untuk mencoba, mengalami, merasakan dan menemukan sendiri apa yang dipelajari pada pelajaran IPS di Sekolah Dasar. Dalam penelitian ini media pembelajaran yang dipakai adalah media pembelajaran kreatif yang dibuat sendiri oleh guru. Dengan media seperti ini, diharapkan mampu meningkatkan hasil belajar IPS siswa Sekolah Dasar Negeri di Surabaya Selatan.

Berikut media pembelajaran kreatif yang digunakan dalam penelitian ini antara lain:

1. Media Drawing Card

Drawing Card adalah media yang terbuat dari karton berbentuk persegi. Pada kartu tedapat gambar tentang suatu peristiwa. Dari media tersebut, guru memberi tugas kepada siswa untuk menceritakan gambar yang terdapat dalam kartu dengan bahasanya sendiri.

2. Media Bopada (Boneka Pahlawan Daerah) Media Bopada jika diklasifikasikan berdasarkan indera yang terlibat merupakan jenis media visual yaitu hanya melibatkan indera penglihatan saja. Bopada merupakan boneka tiruan pahlawan daerah. Boneka Pahlawan ini dibuat semenarik mungkin sehingga dapat meningkatkan motivasi belajar siswa. Siswa dapat mengerti bagaimana karakteristik dari setiap bopada. Dan siswa dapat meneladani kepahlawanan dari setiap Bopada. Media Bopada juga menjadi salah satu media untuk mengimplementasikan pendidikan karakter yang ada di tanah air. Karena dengan media ini guru dapat menanamkan rasa cinta tanah air terhadap siswa dengan meneladani kepahlawanan.

3. Media teka - teki dua dimensi

Media teka-teki 2 dimensi (gambar buka tutup) adalah media yang menggunakan gambar secara samar-samar, kemudian siswa bertugas menjawab soal yang berkaitan dengan gambar tersebut.

4. Karpin (kartu pintar)

Karpin (kartu pintar) digunakan sebagai media pada saat melakukan metode tanya jawab, dimana guru dalam melakukan tanya jawab tidak secara lisan melainkan melalui 
karpin (kartu pintar). Karpin (kartu pintar) terbuat dari potongan kertas yang ukurannya bisa $15 \times 11 \mathrm{~cm}$ atau sebagainya. Media ini (karpin) memungkinkan siswa untuk berkelompok dan menjawab dengan cepat dan benar pertanyaan yang ada pada kartu.

5. Media Terintegrasi (Big Book)

Media terintegrasi (Big Book) merupakan gabungan dari beberapa media pembelajaran yang saling menutupi kekurangan/kelemahan masing-masing media, sehingga terciptalah suatu media pembelajaran yang dapat dikatakan sempurna

(lppm.ut.ac.id/htmpublikasi/sudirman71.pdf ). Media pembelajaran yang digabungkan atau diintegrasikan lebih baik dari media individual karena media terintegrasi dapat menutupi kekurangan-kekurangan yang ada dalam media lain.

6. Media Wayang Tokoh

wayang tokoh adalah sebuah boneka tiruan yang berbentuk menyerupai tokoh anggota keluarga yang dimainkan sesuai materi yang akan dibahas.

Berdasarkan uraian latar belakang tersebut di atas maka dapat dirumuskan masalah yang akan dikaji dalam penelitian ini, adalah "Adakah pengaruh penggunaan media pembelajaran kreatif terhadap hasil belajar IPS siswa Sekolah Dasar Negeri di Surabaya Selatan?". Sedangkan tujuan penelitian ini pada dasarnya ingin mengungkap informasi mengenai masalah yang berkaitan erat dengan pengaruh media pembelajaran kreatif terhadap hasil belajar siswa. Secara ringkas tujuan penelitian ini dapat dijabarkan sebagai berikut: "Mengkaji pengaruh penggunaan media pembelajaran kreatif terhadap hasil belajar IPS siswa Sekolah Dasar Negeri di Surabaya Selatan.

\section{Metode Penelitian}

1. Rancangan Penelitian

Jenis penelitian ini adalah penelitian kuantitatif True Experimental Design dengan jenis postest-only control design. Dikatakan True Experimental Design (eksperimen yang betul-betul), karena dalam desain ini, peneliti dapat mengontrol variabel luar yang mempengaruhi jalannya eksperimen.

2. Populasi

Populasi dalam penelitian ini adalah siswa kelas IV dan V Sekolah Dasar Negeri di Surabaya Selatan yang berjumlah 148 SDN, yang letaknya tersebar di 8 Kecamatan

3. Sampel

Sampel yang digunakan adalah siswa kelas IV dan V di lima SDN di 4 kecamatan dalam lingkup Surabaya Selatan, yaitu: SDN Ngagel Rejo, SDN Margorejo I, SDN Menanggal II, dan SDN Gayungan II. SDN Tenggilis Mejoyo

4. Teknik Pengumpulan Data

Dalam penelitian ini data dikumpulkan dengan teknik tes dan observasi.

a. Tes

Teknik tes digunakan untuk mengumpulkan data yang berkaitan dengan hasil belajar siswa. Teknik tes yang dimaksud adalah Post Tes yang dilaksanakan pada akhir pembelajaran dengan menggunakan seperangkat tes tertulis dalam bentuk pilihan ganda, jawaban singkat, dan uraian untuk mengetahui hasil belajar siswa dalam pembelajaran IPS.

b. Observasi

Observasi yang dimaksud adalah observasi terstruktur, untuk mencari data tentang pengaruh penerapan media pembelajaran kreatif pada mata pelalajaran IPS (keaktivan siswa).

5. Teknik Analisis Data

Teknik analisis data yang digunakan adalah uji t komparatif dua sampel.

\section{Hasil Penlitian}

Hasil belajar siswa dengan penerapan media kreatif sebagai berikut:

1. Penerapan Media Drawing Card di SDN Tenggilis Mejoyo I

Dari analisis diperoleh $t_{\text {hitung }}=4,33$ dan $\mathrm{t}_{\text {tabel }}=2,00$ pada taraf signifikansi sebesar $5 \%$. Karena $t_{\text {hitung }}$ lebih besar dari $t_{\text {tabel }}$ 
maka dapat dinyatakan $\mathrm{H}_{0}$ ditolak dan $\mathrm{H}_{a}$ diterima, yang berarti bahwa penerapan media Drawing Card berpengaruh terhadap hasil belajar IPS kelas V di SDN Tenggilis Mejoyo I Surabaya.

\section{Penerapan Media Bopada di SD Gayungan} II Surabaya

Berdasarkan perhitungan diperoleh $t_{\text {hitung }}=7,62$ dan $t_{\text {tabel }}=1,99$ pada taraf signifikansi $5 \%$. Karena $t_{\text {hitung }}$ lebih besar dari $\mathrm{t}_{\text {tabel }}$ maka dapat dinyatakan $\mathrm{H}_{0}$ ditolak dan $\mathrm{H}_{a}$ diterima, yang membuktikan bahwa pembelajaran dengan menggunakan media BOPADA berpengaruh terhadap hasil belajar dan karakter rasa cinta tanah air. dalam pembelajaran IPS siswa kelas IV SDN Gayungan II/423 Surabaya.

3. Penerapan Media Teka-teki 2 Dimensi (Gambar Buka Tutup) di SDN Gayungan II Surabaya

Berdasarkan analisis data yang telah dilakukan diperoleh hasil nilai $\mathrm{t}_{\text {hitung }}=6,70$ lebih besar dari nilai $\mathrm{t}_{\text {tabel }}=1,997$ pada taraf signifikan sebesar 5\%, maka dapat dinyatakan Ho ditolak dan Ha diterima.

Karena Ho ditolak dan Ha diterima, maka dapat disimpulkan bahwa; "ada pengaruh

yang signifikan penggunaan Media Permainan Teka - Teki 2 Dimensi (Gambar Buka

Tutup) Terhadap Hasil Belajar IPS Siswa Kelas V SDN Gayungan II”.

4. Penerapan Media Karpin di SDN Dukuh Menanggal II/425 Surabaya.

Berdasarkan perhitungan dengan menggunakan rumus uji-t diperoleh nilai $\mathrm{t}_{\text {hitung }}$ sebesar 2,87 dan $\mathrm{t}_{\text {tabel }}$ sebesar 1,667 pada taraf signifikansi $5 \%$, maka dapat disimpulkan bahwa metode tanya jawab dengan karpin (kartu pintar) berpengaruh terhadap hasil belajar IPS siswa kelas V SDN Dukuh Menanggal II/425 Surabaya.

5. Penerapan Media Wayang Tokoh di SDN Ngagel Rejo II Surabaya
Berdasarkan perhitungan dengan menggunakan rumus uji-t diperoleh nilai $\mathrm{t}_{\text {hitung }}$ sebesar 10,03 dan $\mathrm{t}_{\text {tabel }}$ sebesar 1,993 pada taraf signifikansi 5\%. Sebagai konsekuensinya $\mathrm{Ha}$ diterima, maka membuktikan bahwa pembelajaran dengan model discovery learning menggunakan media wayang tokoh berpengaruh terhadap hasil belajar peserta didik di SDN Ngagel Rejo II/397 Surabaya.

\section{Pembahasan}

Berdasarkan hasil analisis tersebut di atas, tampak jelas bahwa penggunaan atau penerapan media pembelajaran, dalam hal ini media kreatif mempunyai pengaruh positif terhadap hasil belajar siswa mata pelajaran Ilmu Pengetahuan Sosial. Media kreatif merupakan media yang dibuat oleh guru disesuaikan dengan pokok bahasan/subpokok bahasan, tema/subtema sehingga benar-benar sesuai dengan materi dan kebutuhan siswa.

Hal ini dapat dilihat misalnya pada penerapan media drawing card, kartu pintar, Teka-teki 2 Dimensi, big book,berfungsi untuk mempermudah siswa meningkatkan ketrampilan berbicara, mengeluarkan pendapat, mengeneralisasi, mengkonkretkan suatu konsep maupun mengatasi keterbatasan ruang dan waktu. Selain itu juga meningkatkan keaktifan dan antusiasme siswa dalam proses pembelajaran. Dengan memadukan metode dan media tersebut membuat proses belajar lebih afektif.

Hamalik (Azhar, 2011:15) mengemukakan bahwa pemakaian media pembelajaran dalam proses belajar mengajar dapat membangkitkan keinginan dan minat yang baru, membangkitkan motivasi dan rangsangan kegiatan belajar, dan bahkan membawa pengaruh - pengaruh psikologis terhadap siswa. Selain untuk merangsang siswa, dapat juga dijadikan komponen untuk menjadikan siswa lebih aktif dalam belajar. Keterlibatan aktif peserta didik dalam roses pembelajaran mengakibatkan terjalinnya komunikasi yang baik antara peserta didik dan guru sehingga tercipta suasana kondusif dalam pembelajaran. 
Menurut Nana Sudjana (2000:37) mendefinisikan hasil belajar siswa pada hakikatnya adalah perubahan tingkah laku dalam pengertian yang lebih luas mencakup bidang kognitif, afektif, dan psikomotorik. Hasil belajar yang dicapai siswa juga dipengaruhi oleh dua faktor yakni faktor dari dalam diri siswa dan faktor dari luar diri siswa (Nana, 2000:39). Hasil belajar merupakan hasil akhir dari pembelajaran yang merupakan ketuntasan siswa dalam suatu proses pembelajaran.

Selain berpengaruh terhadap hasil belajar siswa, penerapan media pembelajaran kreatif juga dapat digunakan untuk meningkatkan/memupuk karakter siswa seperti rasa cinta tanah air, jujur kreatif dan sebagainya, sehingga dapat mendorong siswa menjadi generasi yang senantiasa memiliki sikap yang baik dalam bermasyarakat dengan lingkungan sekitar. Selain itu, siswa menjadi lebih interaktif dan bahkan aktif didalam proses pembelajaran dengan banyak menemukan hal baru yang belum diketahui sebelumnya. Hal ini tampak jelas dalam penerapan media Bopada (Boneka Pahlawan Daerah) dan wayang tokoh.

Seperti yang disampaikan Sadiman (2010:17) bahwa media mempunyai kegunaankegunaan sebagai berikut:

1. Memperjelas penyajian pesan agar tidak terlalu bersifat verbalistis (dalam bentuk kata-kata tertulis atau lisan belaka). Dalam fungsi ini, media berperan membantu siswa dalam memahami suatu contoh dalam bentuk konkret.

2. Mengatasi keterbatasan ruang, waktu, dan panca indera, seperti misalnya:

a. objek yang terlalu besar bisa digantikan dengan realita, gambar, film bingkai, film, atau model.

b. Objek yang kecil dibantu dengan proyektor mikro, film bingkai, film, gambar.

3. Penggunaan media pendidikan secara tepat dan bervariasi dapat mengatasi sikap pasif anak didik. Dalam hal ini media berfungsi untuk:

a. Menimbulkan kegairahan belajar; b. Memungkinkan interaksi yang lebih langsung antara anak didik dengan lingkungan dan kenyataan;

c. Memugkinkan anak didik belajar sendiri-sendiri menurut kemampuan dan minatnya.

Menurut Sudjana (2009:2) media pengajaran dapat mempertinggi proses belajar siswa dalam pengajaran yang pada gilirannya diharapkan dapat mempertinggi hasil belajar yang dicapainya.

\section{Simpulan dan Saran}

\section{Simpulan}

Berdasarkan hasil analisis data dan pembahasan yang disampaikan, maka dapat diberikan simpulan sebagai berikut:

"Ada pengaruh yang signifikan penggunaan Media Pembelajaran Kreatif terhadap hasil belajar IPS siswa Sekolah Dasar Negeri di Surabaya Selatan".

\section{Saran}

Berdasarkan hasil pembahasan yang ditemukan, maka dapat diberikan beberapa saran sebagai berikut :

a. Guru sebaiknya menggunakan media pembelajaran kreatif dalam pembelajaran IPS, dikarenakan media pembelajaran kreatif lebih efektif dan efisien, serta dapat meningkatkan hasil belajar siswa.

b. Mengingat segala keterbatasan penelitian ini, perlu adanya penelitian lebih lanjut sehingga dapat memberikan gambaran yang lebih komperhensif tentang penerapan media pembelajaran kreatif. Untuk penelitian sejenis hendaknya dilakukan penyempurnaan-penyempurnaan agar diperoleh hasil yang lebih optimal dan media pembelajaran kreatif ini dapat digunakan untuk mata pelajaran yang lain.

\section{Daftar Pustaka}

Anggoro, Toha,M,dkk. 2007. Metode Penelitian. Jakarta: Universitas Terbuka. 
Tahun XI, No. 20, April 2015

Arikunto, Suharsimi. 2006. Prosedur Penelitian Pendekatan Praktik. Jakarta: Rinaka Cipta.

Kemendiknas Badan Penelitian dan Pengembangan Pusat Kurikulum, 2010, Pengembangan Pendidikan Budaya dan Karakter Bangsa, Jakarta: Kemendiknas.

Majid, Abdul. 2008. Perencanaan Pembelajaran. Bandung : PT Remaja Rosdakarya

Mandela. 2012. “Model Cooperative Learning Tipe Numbered Heads Together (NHT) Dengan Penggunaan LKS Terhadap Peningkatan Hasil Belajar Siswa SMP Pada Mata Pelajaran TIK". http://repository.upi.edu/tesisview.php? no_tesis $=10664$.

Ma'mur,Asmani,Jamal. 2011. 7 Tips Aplikasi PAIKEM. Jogjakarta: DIVA Press

Nazir, Moh, . 1983. Metodologi Penelitian. Darussalam: Ghalia Indonesia

Nur Aini. 2011 "Pengertian Karakteristik IPS di SD" http://naiwa85.blogspot.com/2011/10/karakteristikips-sd-menurut-ahli-asing.html.
Permana. 2011. "Mengembangkan Pembelajaran Sejarah Yang Bermakna Melalui Penggunaan LKS Kontekstual Pada Siswa XI SMA". http://repository.upi.edu/tesisview.php? no tesis $=2200$.

Sapriya., Susilawati, and Nurdin,Sadjaruddin. 2008. Konsep Dasar IPS.

Sugiyono,Prof. 2011. Metode Penelitian Kuantitatif Kualitatif dan $R$ \& $D$. Bandung: Alfabeta.

Siregar, Evaline, dan Nara, Hartini. 2010. Teori Belajar dan Pembelajaran. Bogor: Ghalia Indonesia.

Sudjana,Nana,.2008. Penilaian Hasil Proses Belajar Mengajar. Bandung: PT Remaja Rosda Karya.

Wahid Ibnu. 2011 "Pengembangan Lembar Kerja Siswa Bercirikan Penyelesaian Masalah Model Polya Materi Barisan dan Deret pada Siswa SMK" http://karyailmiah.um.ac.id/index.php/disertasi/arti cle/view/14090.

Wina, Sanjaya, M.Pd. 2008. Perencenaan dan Desain Sistem Pembelajaran. Bandung : Kencana Media Group. 